\title{
Symbiotic Relations of Sediment- Agglutinating Nematodes and Bacteria in Detrital Habitats: The Enzyme-Sharing Concept
}

\author{
Franz Riemann* \& Elisabeth Helmke
}

\begin{abstract}
Alfred-Wegener-Institut für Polar- und Meeresforschung, D 27515 Bremerhaven, Germany.
With 5 figures
\end{abstract}

Keywords: Benthic marine nematodes, detritus, bacteria, polysaccharides, decomposition, enzymes, mucus, food chain.

\begin{abstract}
A new concept ('enzyme sharing') concerning the interaction of marine nematodes and microbes in the degradation of sedimentary detritus is presented. Elements of this concept are (1) the notorious tendency of many aquatic nematodes to agglutinate detrital particles by mucus secretions, (2) new observations on the stimulation of microbial growth by nematodes in agar plates, and (3) literature data on limited endogenous proteolytic capacities of aquatic nematodes.
\end{abstract}

Observations on nematode-microbe associations in agar plates prompted the conceptual synthesis. In agar medium without the addition of any nutrients a spectacular growth of bacteria was visible on the sinusoidal crawling trails of nematodes only 2-3 days after introduction of the worms (species of Adoncholaimus, Anoplostoma and Sabatieria). Juveniles of Anoplostoma that hatched in the agar cultures left their minute trails in the medium and these were rapidly occupied by bacteria. The nematodes repeatedly visited their bacterial trails, which persisted as a peculiar biotic structure for more than one year and survived the nematodes.

In sterile agar preparations containing the fluorogenic methylumbelliferyl- $\beta$-glucoside in the presence of the nematode Adoncholaimus, an enhanced fluorescence of the medium was visible, indicating $\beta$-glucosidase activity. We therefore assume that oncholaimid nematodes discharge enzymes that alone, or in concert with microbial activities, contribute to the hydrolytic cleavage of refractory polysaccharides containing $\beta$-glucosidic bonds such as agar components and cellulose. The sugars thus produced may then be taken up by the nematodes and concomitantly support the conspicuous growth of microbes. Since we did not observe any feeding of the nematodes on the associated microbes in agar plates, we question the nutritive potential of intact microbial cells for a

\footnotetext{
* Author to whom correspondence should be addressed. E-mail: friemann@awi-bremerhaven.de
} 
number of nematodes abounding in detrital habitats, and call attention to the significance of ambient dissolved or adsorbed organic monomeric nutrients.

Consequently, we perceive the puzzling perpetual accretion of detrital organic particles to sediment agglutinations by nematodes as an adaptation for operating an 'enzymatic reactor' for the production of dissolved nutrients. We hypothesise a relationship of mutual commensalism of nematodes and heterotrophic microbes in detrital habitats and propose the term 'enzyme sharing' for this relationship. Both parties invest in a common enzyme pool that decomposes organic detritus for their nutrition. We present here evidence that nematodes contribute $\beta$-glucosidase, which is involved in the cellulase system. Data from the literature suggest that microbial enzymatic processing of detrital proteins yields amino acids available to nematodes, which apparently have no efficient proteolytic enzyme system in their intestines.

\section{Problem}

Nematodes are the most abundant microscopic metazoans in marine sediments, and their ecological significance is great in terms of productivity, food-chain relationships, and remineralisation of organic substances (reviews by Platt \& Warwick, 1980; Heip et al., 1985). In our opinion, however, the most obvious environmental impact of a great number of marine nematode species is linked with their capacity to agglutinate detrital particles, thus forming lumps or burrows in the size range of a few millimetres (Riemann \& Schrage, 1978). As a result, there appears to be no square centimetre of marine soft bottoms, world-wide, that is not affected by the nematodes' mucus secretions.

In laboratory conditions the nematodes accumulate particles by glueing them together with mucus within a few minutes after their introduction into a vessel. Potential mucus-producing organs are the caudal glands, pharyngeal glands, large ventral glands (excretory gland, renette) and small epidermal glands. Curiously, this particle accumulation remained almost unnoted by nematologists until a novice in the field (Meschkat, 1934) gave the first detailed description of it. He investigated an epiphytic diatom-nematode community thriving on reed stalks in the Hungarian Lake Balaton. The nematodes (members of the family Chromadoridae, which are also abundant in marine habitats) continuously produce slimy trails which entrap particles from the ambient turbid water. The mucus threads are then reinforced by the worms repeatedly crawling along the trails. In the presence of many nematodes in a petri dish, Meschkat observed the appearance of a framework of detrital mucus paths in which the nematodes built globular detrital accumulations up to the size of a pea and in which great numbers of the worms aggregated. He was unable to stain the very sticky and contractile mucus threads, but these were made visible by the particles attached to them. The amount of the mucus excreted cannot be estimated from Meschkat's descriptions, but in a fascinating observation on chromadorid nematodes in Danish lakes, Wesenberg-Lund (1939, pp. 284-286) described a considerable production of thick, jelly-like strings by these nematodes, which were attached to the leaves of the macrophyte Potamogeton. 


\section{Mucus-secreting glands and supposed functions}

Meschkat (1934) related the production of sediment agglutinations to the chromadorids' caudal glands, and, from his figures and the description of the relevant processes, it becomes clear that these secretions are effective in the deposition of extended, particle-loaded mucus threads. However, the description of the formation of sediment balls, in which the chromadorids aggregate, is suggestive of quite another process. In this case the worms are anchored by the posterior part of the body and perform swinging movements with the anterior end, whereby they catch and agglutinate sediment particles from the vicinity. The particle capture is obviously achieved by a sticky mucus source in the head region of the nematode and the increasing agglutination then surrounds the posterior region (Fig. 1).

A similar activity has been described by Nehring et al. (1990) in a study on marine littoral chromadorid nematodes from soft sediments (Ptycholaimellus spp.). These nematodes construct detrital tubes by means of mucus released, in the opinion of those

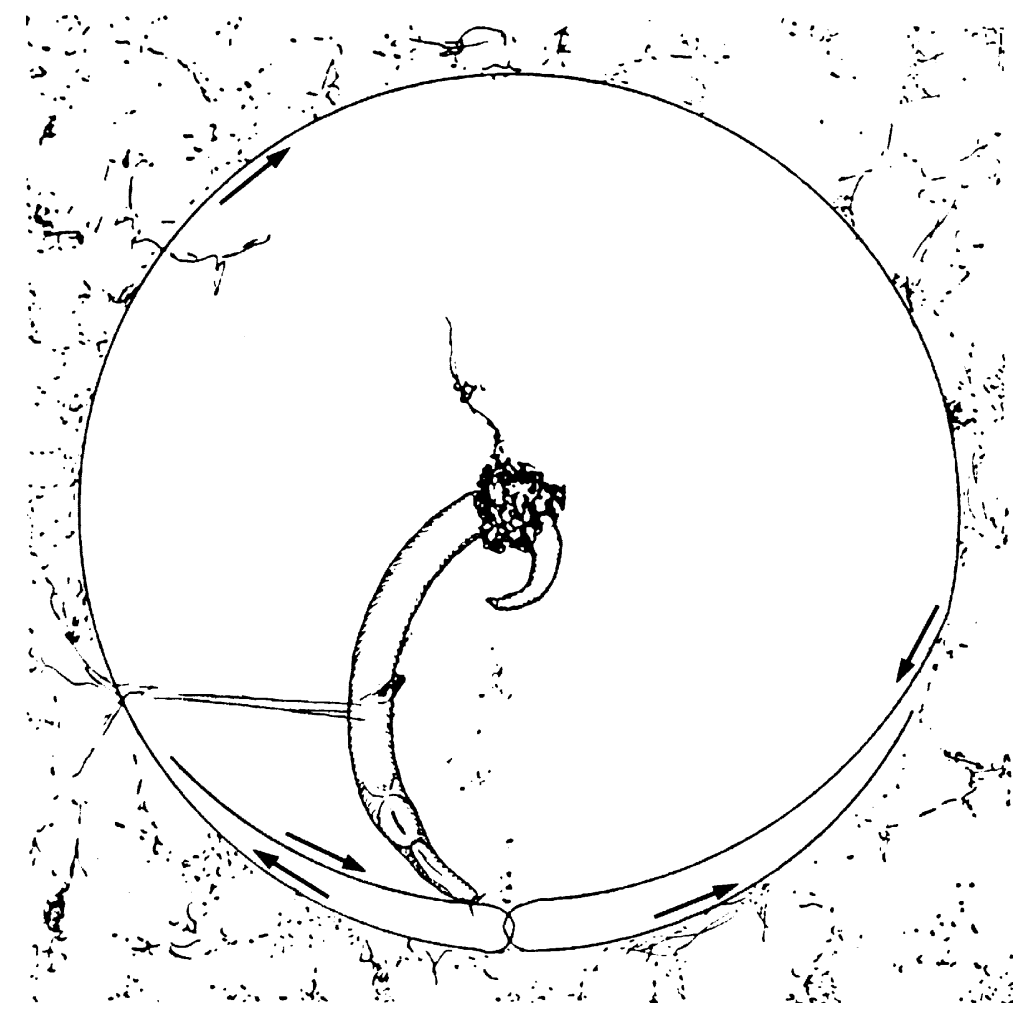

Fig. 1. Formation of detritus agglutinations: Chromadorid nematode (presumably Punctodora ratzeburgensis) fixed with the tail end to a flat surface and collecting detrital particles from the surroundings by performing swinging, sweeping movements in either direction (arrows) with the anterior end in the dorsoventral plane. The particles adhere to mucus secretions and are concentrated near the posterior end of the worm (after Meschkat, 1934). 
authors, by a large ventral gland cell, which opens close to the lips and, probably, also from hypodermal gland cells distributed along the body wall. Riemann \& Schrage (1978) related the stickiness of the mouth region in marine nematodes of several families to the discharge of secretions from pharyngeal salivary glands (see also Bongers, 1983) and believed this indicates extra-oral digestion in some marine nematodes. A similar digestive function was subsequently proposed also for nematode species in which the exit pore of the ventral gland opens into the mouth cavity (Coomans \& De Waele, 1979). In a study of the ultrastructure of the marine nematode Monhystera disjuncta, Van de Velde \& Coomans (1987) suggested that the ventral gland system of this species, which opens close to the mouth, may have an important exodigestive function compensating for the rather poorly developed pharyngeal glands. Live observations of this species (Riemann \& Schrage, 1978) actually demonstrated mucus discharge from the mouth region. Lorenzen (1979) tentatively related the production of slimy tubes in Monhystera pusilla to secretions from the ventral gland. However, in all these instances, where the orifice of the ventral gland is near the mouth opening, the combined contribution of pharyngeal and ventral glands to mucus discharge cannot be ruled out. In Sphaerolaimus gracilis, where the ventral gland pore is located far behind the mouth, Turpeeniemi \& Hyvärinen (1996) noted the distinct stickiness of the pore region, which may anchor the worm at that point, but a mucus flow was not observed.

\section{Significance of detritus agglutinations}

To date, there is no unequivocal general explanation of the significance of detritus agglutinations for the nematodes. Meschkat (1934) assumed a nutritional effect for the chromadorid nematodes, perhaps with the participation of bacteria, but this assumption is presented only in the summary. Riemann \& Schrage (1978) continued Meschkat's experiments with several marine and brackish-water species and found a considerable microbial growth on their mucus threads and within their detrital agglutinations. They then formulated their 'mucus-trap hypothesis': "With their mucus threads these nematodes entrap small detritus particles, bacteria, and macromolecules which subsequently are browsed together with the mucus. The combination of an adhesive mucus thread and the particular mouth construction in nematodes represents a highly elaborated collecting and sorting system for food acquisition. In addition, decomposition processes of organic material coated by the mucus may contribute to a secondary food source which is controlled by nematodes."

Amendments and critical comments to these sentences need to be made. (1) Bacteria grow in the detrital agglutinations; they are not "trapped" as the wording may suggest. The mucus threads proved to be sticky for detrital organic and mineral particles, but not for floating bacteria and other microbes (F. Riemann, unpubl. observ.). It remained unknown whether the microbes grow on attached minute detrital particles or directly on mucus produced by the nematodes. (2) The hypothesised feeding of detritus-agglutinating nematodes on microbes growing in the agglutinations has not been observed. This negative result contrasted with the contemporary paradigm according to which bacteria constitute the main food of meiofauna (Gerlach, 1978). In the case of oncholaimid nematodes, which are abundant inhabitants of coastal sediments and apparently feed on the bacteria-detritus complex, the use of dissolved organic substances from the ambient 
water has been demonstrated (Chia \& Warwick, 1969; Lopez et al., 1979; Riemann et al., 1990). According to studies with radioactive isotope techniques, bacteria cell bodies are unlikely to constitute a significant food for these nematodes (Lopez et al., 1979; Moens et al., 1999).

A quite different line of argument explaining the production of detrital agglutinations and, more generally, the preference of many nematodes for viscous microhabitats, including those produced by other organisms, was presented by Riemann (1995). In that study, attention was directed to physical rather than to nutritional aspects. Nematodes usually cannot move and feed properly in fluffy surficial detritus deposits because the typical wave-like or undulatory propulsion of the worms requires the presence of an external resistance against which the waves can exert the propulsion. Observations on the distribution of nematodes in flocculent muds prompted these considerations. Meschkat (1934) had already described how, once the chromadorid nematodes had established the mucus-detritus framework in the vessels, their locomotion became very dexterous. An enigmatic attraction of marine nematodes to agar media was discussed by Riemann (1995) as a preference for a comparatively viscous habitat.

\section{Promotion of microbial growth}

Cayrol \& Dreyfus (1975; see also Cayrol \& B'chir, 1973) noted growth of bacteria in agar plate cultures with soil nematodes (Order Rhabditida), even after previous shortterm washing with antibiotics. They concluded that these nematodes disseminate the microbes, which obviously persisted in the nematodes' intestines, and promote their growth by means of secretions discharged into the medium. Thereby, each species of nematode was associated with a specific assemblage (2-3 species) of bacteria. From the short notes of these authors we cannot determine how they assessed the special growth-promoting factors produced by nematodes because agar with copious amounts of nutrients was used.

A specific association of a marine nematode species with microbes was discovered by Warwick (1981), who found monospecific concentrations of a small unicellular alga (Tetraselmis, Chlorophyta) on the sinusoidal trails of Praeacanthonchus (Order Chromadorida) in agar plate cultures. He used nutrient agar and a natural mixture of microorganisms from the mud-flat of an English estuary and hypothesised the ingestion of the algae by the nematodes.

Jensen (1996), also using agar with nutrients, pointed to the growth of heterotrophic microbes on the trails of other nematodes. He investigated six marine nematode species belonging to four families, most of them common in coastal muddy habitats. The observed mass occurrence of protists and bacteria in sinusoidal burrows in the agar was interpreted as the result of a mechanical distribution of microbes by the nematodes, with a subsequent strong growth in the agar. Jensen presented instructive micrographs displaying various burrow shapes (hollow or filled by microbes, tapering or with even diameters) which were made visible by the colonising microbes. No discharge of mucus threads was observed in the study and no evidence was presented of the ingestion of the associated microbes, though most of the nematode species observed were believed to be bacteria-feeders. 
In contrast to all culture assays mentioned above, Riemann (1986) and Riemann \& Schrage (1988) added no nutrients to the agar media. Despite this deficiency they observed a conspicuous growth of micro-organisms on the trails of oncholaimid nematodes. Riemann (1986) assumed that nematode secretions had promoted the microbe growth; the benefits of these microbes for the nematodes remained unexplained.

\section{Aims of the present study}

First, we report on observations made on the effects and behaviour of three common nematode species in oligotrophic agar media and describe and illustrate details of the conspicuous aggregations of microbes on their trails. Our main test subject was an oncholaimid, Adoncholaimus thalassophygas (de Man 1876). Second, we examined potential glands for mucus discharge and the capacity of the secretions to support a microbial growth within the agglutination of mineral particles. Finally, we examined whether oncholaimid nematodes can discharge an enzyme that alone, or in concert with microbial activities, hydrolytically cleaves components of agar polysaccharides, thus yielding small oligomers or monomeric carbohydrates which support microbial growth. As a candidate enzyme, we selected $\beta$-glucosidase because a cellulolytic activity of nematodes involving that type of enzyme has long been suspected. Franz (1942) reared soil nematodes on pure cellulose filter paper in a petri dish and observed the degradation of the paper. He concluded that particular saprobic species feed on carbohydrates, intimately cooperating with cellulose-degrading bacteria and essentially participating in the cellulose decomposition during decay processes. Furthermore, there is a long series of studies on cellulase production in plant-parasitic nematodes (reviewed by Deubert \& Rohde, 1971; Lee \& Atkinson, 1976), beginning with Tracey (1958). Recently, Smant et al. (1998) demonstrated the presence of endogenous cellulases $(\beta$-1,4-endoglucanase) in plant-parasitic nematodes with molecular biological methods, at the same time stressing that endogenous cellulase production by animals seems exceptional. In general, cellulose digestion in herbivorous animals is mediated by microorganisms. Deubert \& Rohde (1971, p. 86) reported that tylenchid nematodes "left tracks in agar, possibly through enzymatic cleavage of glycosidic linkages"; they credited this observation to Mountain \& Patrick (1959), but we were unable to find a relevant description in that article. We tried to visualise the suspected enzyme discharge by mixing a fluorogenic methylumbelliferyl- $\beta$-glucoside (Hoppe, 1983) into the agar.

\section{Material and Methods}

\section{Sampling}

Nematodes were collected between 1997 and 2000 from the Weser estuary, from a mudflat in the entrance to the Bremerhaven fishery harbour. Samples were taken at mid-tide level in brackish water (S about 5). We selected three species which are abundant at this locality over most of the year: Adoncholaimus thalassophygas (de Man 1876) (Oncholaimidae), Anoplostoma viviparum (Bastian 1865) (Anoplostomatidae) and Sabatieria pulchra (Schneider 1906) (Comesomatidae) [in the following text we refer to them by their generic names only]. Adoncholaimus and Anoplostoma occur together close to the sediment surface, and Sabatieria is abundant in black sulfidic muddy sand about $1 \mathrm{~cm}$ below the sediment surface. The gut contents of all three 
species consist of small detrital particles, though adult Adoncholaimus occasionally feed on small injured or dead animals. The nematodes were concentrated with the sieving and decanting method and isolated with hook-bent small needles and collected in small boveri dishes in $3 \mathrm{ml}$ water without detritus. The animals are about $1.5-2 \mathrm{~mm}$ long and $50-70 \mu \mathrm{m}$ in diameter; they crawl at speeds of a few millimetres per minute through the substrate and can be conveniently transported with the needles.

\section{Experiments}

Nematodes were transferred with needles into sloppy agar (heat-sterilised 0.5\% Difco Bacto Agar medium made with brackish water taken from the collection site and with no nutrients added) in petri dishes $(7 \mathrm{~cm}$ diameter). The depth of the agar layer was about $5 \mathrm{~mm}$. The nematodes were introduced immediately after cooling of the agar, and the cover was sealed with Parafilm (American Can Company), allowing gas exchange. The dishes were incubated upside down (with a hanging agar layer) at $18^{\circ} \mathrm{C}$ in a thermostat cupboard. Under these conditions, Adoncholaimus remained active for more than 58 days, Anoplostoma for about one week, but Sabatieria was motile for only about one day (their bodies, however, appeared almost undecomposed even three weeks later). Microscopy was performed with a Zeiss Axioplan microscope with Zeiss micrographic equipment using bright-field and Nomarski techniques. For the observation of bacteria aggregates on the nematodes' trails in the turbid agar plates we used an oblique illumination technique $(2.5 \times$ Neofluar objective, bright-field condenser n. a. 0.24, diaphragm slightly decentred) that highlighted the masses of bacteria. A video camera with printer (AVT Horn, Aalen, Germany, and Sony, Japan) was used to record time series observations.

Experiments to demonstrate mucus discharge and to examine microbial growth in mineral substrates were conducted with sterile fine sand (median diameter $30 \mu \mathrm{m}$ ) and diatomaceous earth (Merck) in brackish water in boveri dishes $(3 \mathrm{ml}$ ). Alcian Blue 8GS (Sigma) dissolved in distilled water was used to stain mucus after membrane filtration of the solution.

$\beta$-glucosidase activity was visualised using a method adopted from Hoppe (1983), who introduced a fluorogenic methylumbelliferyl-substrate (MUF) to measure the enzyme activity in brackish waters. Since contaminant micro-organisms, particularly fungi, may display strong $\beta$-glucosidase activities, axenisation procedures with the nematodes were indispensable. Freshly collected Adoncholaimus were kept in boveri dishes with brackish water containing the bacteriostatic Chloramphenicol $(50 \mathrm{ppm})$ and the fungicide Actidione (=Cycloheximide, Serva, $25 \mathrm{ppm}$ ) for three days before being transferred into the test substrate. MUF- $\beta$-glucoside (Sigma) was dissolved in brackish water up to saturation and was then membrane filtered. This solution was mixed $1: 1 \mathrm{v} / \mathrm{v}$ with warm $1 \%$ sterile agar made up with brackish water, yielding halfsaturated MUF-substrate in $0.5 \%$ sloppy agar. One drop (50 or $100 \mu \mathrm{l})$ of the warm agar-MUF substrate was placed on a microscopic slide. After cooling to room temperature (during which time the drop was protected by a petri dish), 20 Adoncholaimus were transferred with a hook-bent needle into the solidified drop and protected with an $18 \times 18 \mathrm{~mm}$ cover slip. The slides were incubated at $22^{\circ} \mathrm{C}$. The fluorescence of the substrate was examined (Zeiss Standard microscope with epifluorescence equipment, filter set 02, G 365, LP 420) under UV excitation at intervals of about two hours, beginning two hours after starting the incubation. After $24 \mathrm{~h}$ the preparations were microscopically examined for the absence of microbes in the agar (Nomarski technique). Two test runs were performed in April 2000, each consisting of three preparations with nematodes and two controls without nematodes. Preliminary tests without the use of antibiotics and tests with the addition of antibiotics during the incubation with MUF-substrates were also conducted.

\section{Results}

\section{Promotion of microbial growth in oligotrophic agar plates}

Within only two or three days after introducing the nematodes (batches of 10 worms or less) into the sterile agar plates, nematode crawling trails became clearly visible to the naked eye. Using obliquely incident light the sinusoidal trails could be recognised by 


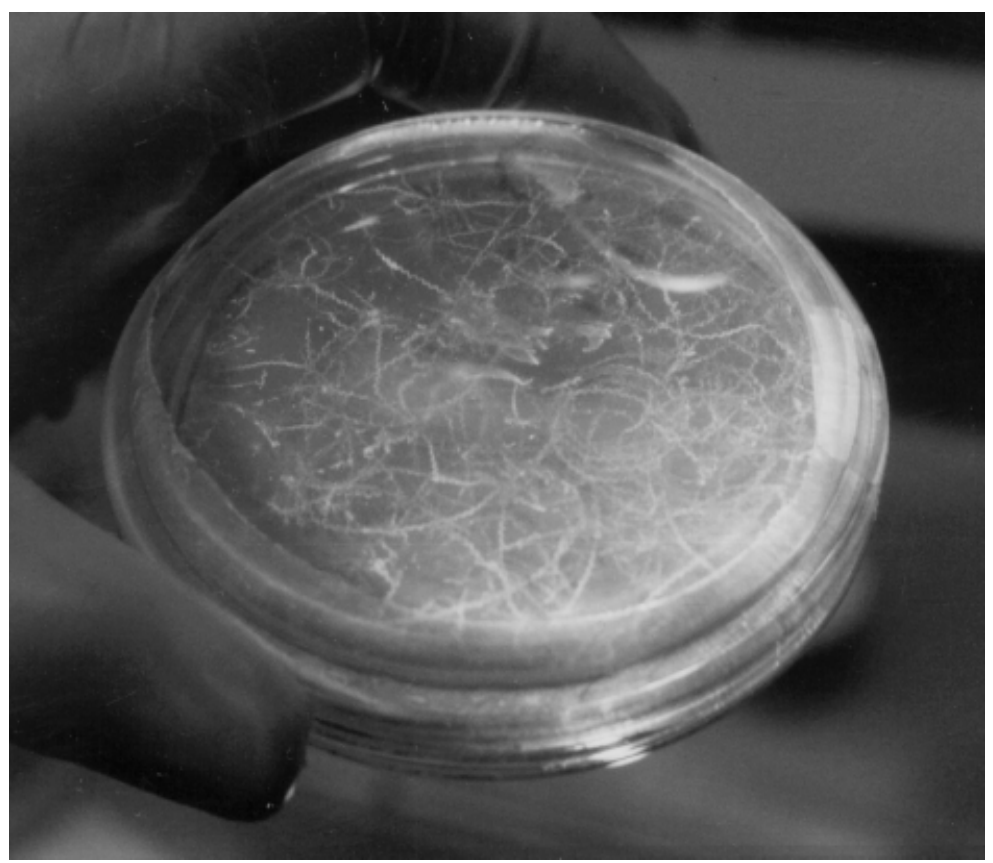

Fig. 2. Agar plate in a petri dish with crawling trails of nematodes highlighted by dense aggregations of bacteria. The photograph was taken four days after the introduction of six Adoncholaimus thalassophygas. An enlarged detail of an earlier developmental stage of the same agar plate is presented on Fig. 3C.

their colonisation with shining, white masses of bacteria (Fig. 2). This spectacular microbial growth occurred in most culture assays (about 50 experiments since 1985) using the three species, Adoncholaimus thalassophygas, Anoplostoma viviparum and Sabatieria pulchra (Figs. 3-5). A more or less dense entanglement of trails highlighted by bacteria crossed the agar plate, with some sections visible as continuous traces over distances up to $2-3 \mathrm{~cm}$. The bacteria aggregates were confined to the nematode trails, except for the places where the animals had been introduced with needles and those sites where nematodes had perished. The trails (here applied to tracks or burrows marked by bacteria) precisely traced the course of the undulatory locomotion of nematodes, following regular sine curves with a wavelength of about $1 \mathrm{~mm}$.

In addition to these large trails, minute trails with a wavelength of only about $0.3 \mathrm{~mm}$ were observed in cultures of Anoplostoma (Fig. 4). The small trails branched off the normal trails or ran alongside them and were also filled with homogeneous masses of bacteria. We attribute these miniature trails to freshly born, about $0.4 \mathrm{~mm}$ long, active juveniles which could be observed in the agar at the same time (Anoplostoma viviparum, as its specific epithet suggests, is a viviparous species).

The microbe-containing trails are similar in general shape and persistence in all three species examined, though individuals of Sabatieria pulchra, which are short-lived in agar plates, produced rather few trails. The following description refers mainly to cultures with Adoncholaimus thalassophygas, which is long-lived in agar. 

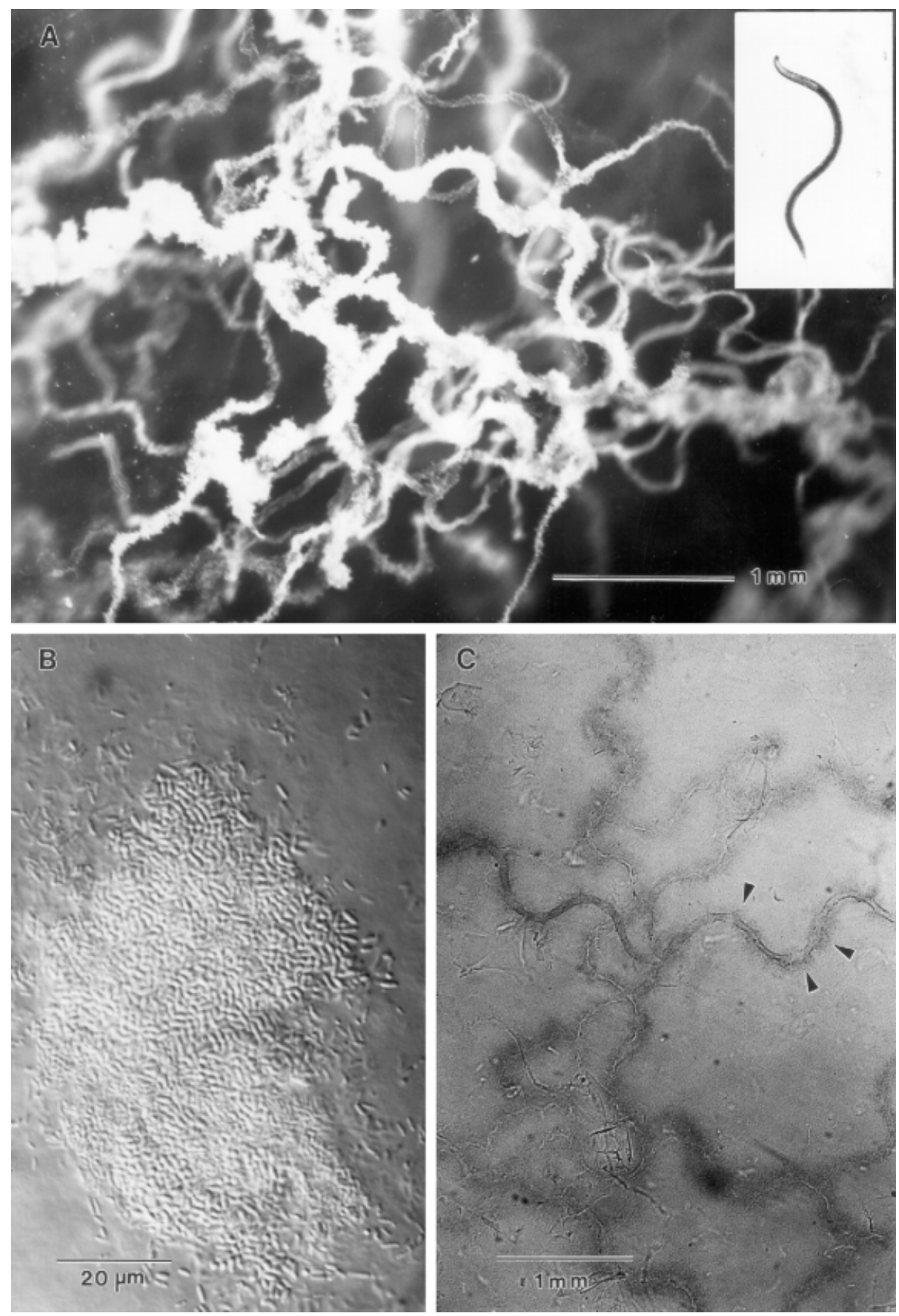

Fig. 3. Trails of Adoncholaimus thalassophygas with bacterial aggregates. A. Overview, oblique illumination (3-day-old culture). Insert shows the nematode. B. Bacterial aggregate, Nomarski photograph (7 d). C. Overview, bright-field, diaphragm stopped right down. Arrows pointing to gaps in the burrow walls with extruded bacterial masses $(2 \mathrm{~d})$. 

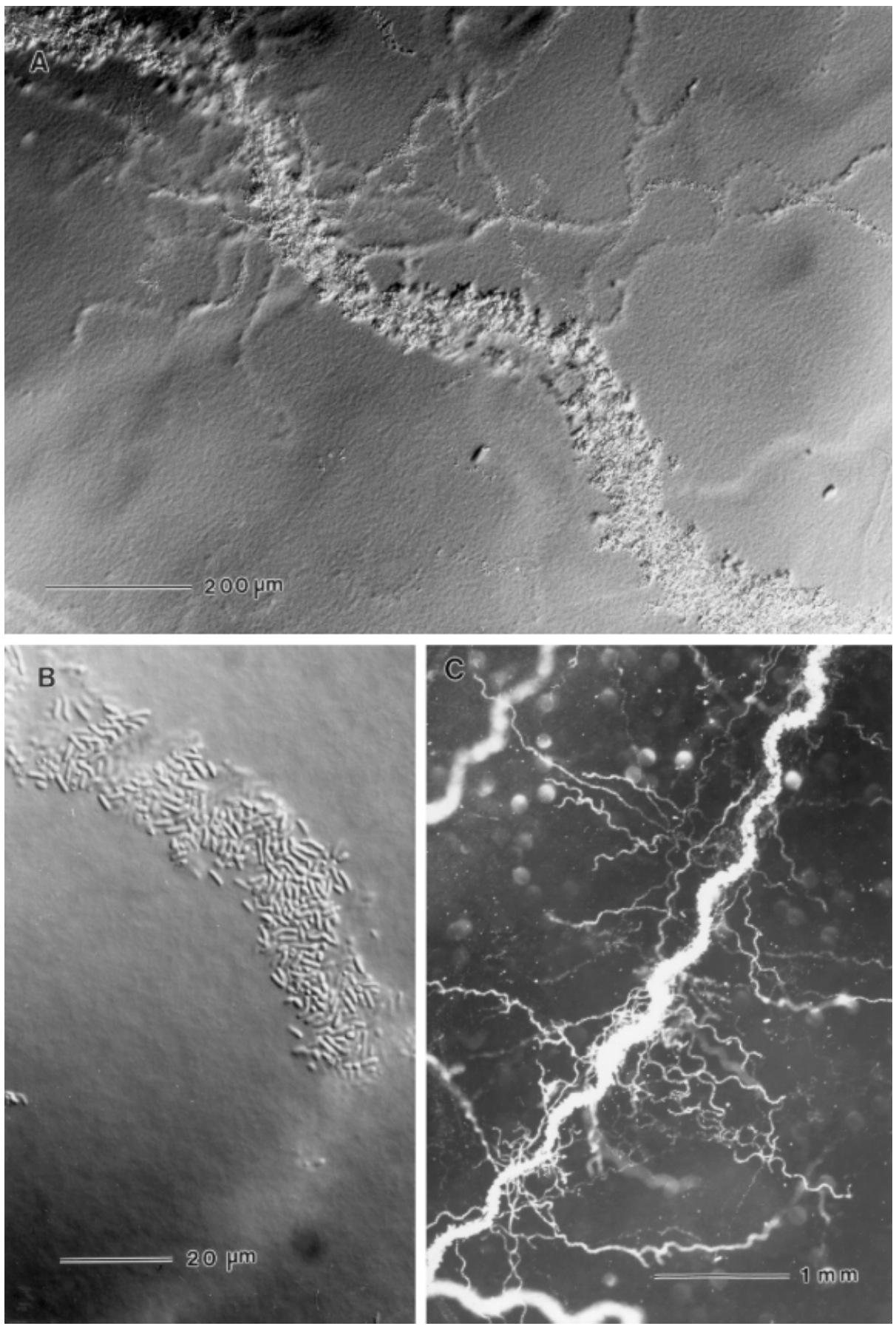

Fig. 4. Trails of Anoplostoma viviparum with bacterial aggregates. A. Nomarski photograph, showing the trail of a mature female with the trails of juveniles branching off (28-day-old culture). B. Bacteria from the trail of a juvenile $(30 \mathrm{~d})$. C. Overview, oblique illumination. Note sections of trails of juveniles extending along the maternal trail (18 d). 

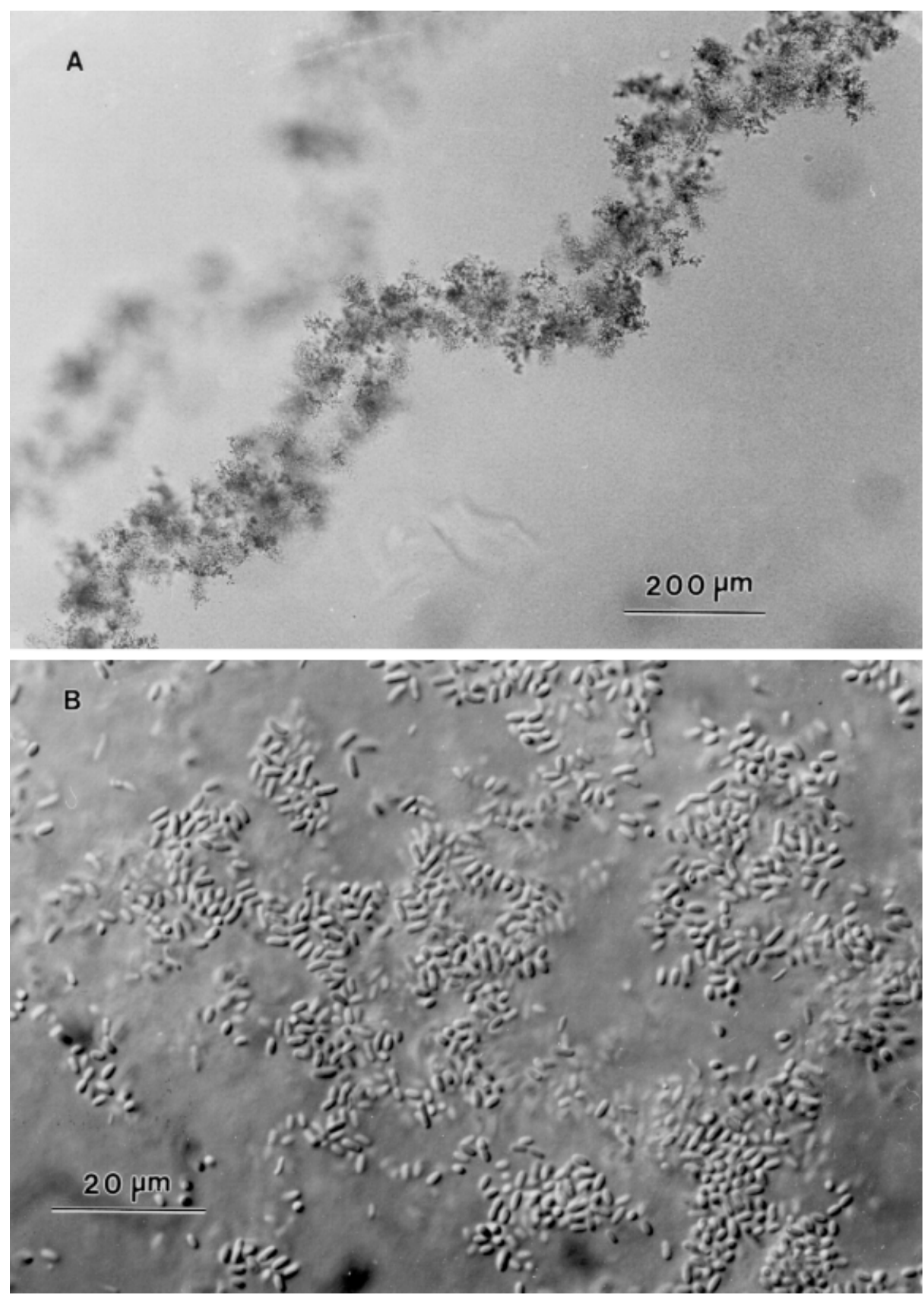

Fig. 5. Trail of Sabatieria pulchra with bacterial aggregates. A. Overview. B. Detail, slightly squeezed (23-day-old culture). 
Most of the trails had a thickness corresponding approximately to the diameter of the nematodes, i. e. 50-70 $\mu \mathrm{m}$. A few trails were smooth, but most had a rough, fringed contour. In addition, there were distinctly thinner trails, sometimes no more than one quarter of the nematodes' diameter; these thin trails may occupy web-like areas. Other trails were very broad, up to ten times the nematodes' diameter; the contours of such trails, which may appear in only 3-day-old cultures, were diffuse. Sometimes a slender, sharply contoured trail widened to a broad, diffuse structure. The trails may branch (Fig. 3A) or they may run almost parallel to each other and converge. Occasionally, very short sections of trails were visible, densely filled with bacteria, and with no obvious connection to other trails. Sinusoidal trails were laid down in all planes, but the horizontal plane was preferred even in 1-cm-thick agar plates. The trails occurred deep in the agar as well as in the contact zone with the glass bottom.

The dense whitish masses of bacteria appeared homogeneous. With the light microscope we were unable to recognise morphological differences in the bulk of bacteria (short rods, about $3 \mu \mathrm{m}$ long) associated with any of the three nematode species. In young cultures there were lively movements of bacteria in the interior of the bacterial masses, also in the miniature trails of the Anoplostoma juveniles. Within compact bacterial strings, the movements were detectable in the interior even after four weeks, while bacteria at the periphery of the trails were immobile. Besides bacteria, in a few cases aggregates of colourless, round, 5- $\mu \mathrm{m}$-large flagellates were observed on the trails of all three nematode species.

Bacterial aggregates were visible under the microscope at the earliest one day after the start of the incubations. By day two or three, massive bacterial strings were clearly visible with the naked eye. These observations suggest an unusually rapid, short-term growth of bacteria associated with nematodes. The spectacular pulse-like growth was restricted to a time span of a few days only, and by about one week after introducing the nematodes we did not observe any further extension of the bacterial masses or increase in the number of trails. Videoprints are available that demonstrate that there were no changes in the Adoncholaimus trails between day 3 and day 7, though the trail pattern was retained in cultures of this species for more than one year. The Anoplostoma trails did not change (judged by comparison of videoprints) between day 5 and day 40 after the start of the incubation, and the minute sinusoidal trails of juvenile Anoplostoma, highlighted by their bacteria, remained distinct even after six months. However, no living Anoplostoma were found in petri dishes after a 14-day incubation: the dormant bacterial aggregates, as a peculiar biogenic structure in a homogeneous medium, survived the lives of the trail producers for several months.

Some low magnification observations indicate that the nematodes repeatedly visit their trails and crawl along the preformed traces. Branchings, convergences and anastomoses (Fig. 3A) indirectly suggest repeated visits to the same trail. Direct observations were rare, and only once during a 30 minute period of continuous observation did an adult Adoncholaimus crawl for $3 \mathrm{~mm}$ within the bacterial masses, thereby exactly following the sinusoidal, preformed trail. Anoplostoma juveniles were observed crawling within the trails of the adults.

Additional live observations were made at high magnification to elucidate the behaviour of Adoncholaimus and its relationships with the associated bacteria in very fresh culture assays, i.e. four hours to three days after introducing the nematodes into the agar. The nematodes crawled almost continuously through the agar, frequently chang- 
ing direction and moving tail first. In this way, they moved to and from up to five times past one spot. This behaviour was reminiscent of a kind of scouring.

No ingestion of bacterial cells or discharge of mucus was observed. Occasionally, crawling nematodes drew a fine trail of shining bacterial cells behind the tail, but we could not discern whether invisible mucus was involved or whether a suction effect transported the bacteria. In one case a nematode crossed a trail filled with bacteria from which bacterial masses were streaming into the fresh burrow.

While crawling through the agar the nematodes sometimes left no visible trace. Often, however, the formation of a distinct burrow was observed (Fig. 3C), whose diameter was equal to or slightly less than that of the worm. The burrows were lined by scale-like, strongly light-refractive wall structures with variable gaps between them. Extended areas were occupied by anastomosing burrows, some sections being filled with bacteria, others remaining empty. Near burrows we observed other trails occupied by bacteria, but without any wall structures. There are indications that repeated visits of the trails may influence the formation and later modification of the burrows and their contents. Frequently, the burrow walls were bent to the outside at the gaps and masses of bacteria were concentrated here (Fig. 3C). We sometimes observed a central canal containing comparatively few bacteria in broad, conspicuous, bacteria-filled trails with diffuse contours. All these observations indicate that nematodes have squeezed and extruded the symbiotic bacteria out of the narrow burrows during repeated visits. These processes must have occurred within the first hours and days after introducing the nematodes into the oligotrophic batch cultures, because there was no further multiplication and distribution of the bacteria after that time, as has been mentioned earlier.

\section{Observations on mucus discharge and mucus properties}

Immediately after their introduction into boveri dishes filled with brackish water and some diatomaceous earth (20 mg), individuals (10-20) of Adoncholaimus agglutinated fine siliceous particles and hid in the lumps. The agglutination was less conspicuous in fine sand, but even here the coherence of grains allowed the transport of agglutinated lumps with a needle after several days. Microscopic inspection of such small lumps after 14 days (sand) and 8 days (diatomaceous earth) stained with Alcian Blue revealed the absence of any microbial aggregates; only a few single bacteria and small flagellates were observed. Some stained droplets adhered to the particles and were assumed to be contracted portions of mucus threads. In conclusion, there was no indication that mucus secretions of nematodes per se would support substantial amounts of microbes in the absence of organic detrital particles.

Live observations were made with Adoncholaimus thalassophygas and Anoplostoma viviparum to identify the sites of mucus discharge and to visualise this discharge by staining. If Adoncholaimus is touched with a needle at the caudal end, the worm sometimes adheres to the needle tip. With the nematode fixed in this way we observed that the head end is sticky, taking up diatom shell fragments from the bottom of the boveri dish. The pore of the ventral gland, which is located two head widths behind the anterior 
end, showed no accumulation of particles. We then conducted experiments in which pieces of cellulose tissue were laid on the siliceous sediment. While climbing and fastening with the tail end within the meshes of the cellulose tissue, worms continuously swept the substratum with swinging movements of the anterior body. They thereby attached siliceous particles taken up from the substratum to the tissue fibres at places well above the bottom and formed globular agglutinations. From these observations, we estimate the share of mucus derived from the head end in Adoncholaimus to be as high or even higher than that secreted from the caudal glands during the formation of sediment agglutinations. In contrast, the head end of Anoplostoma is only slightly sticky, and these nematodes take up only a few particles from the ground with that region. The main agglutination is produced by the caudal gland secretions, even when the worm is hanging between cellulose fibres and is collecting sediment particles from the ground beneath, as was described for Adoncholaimus. The posterior end of Anoplostoma with the long, whip-like tail performs vigorous, undulatory movements during this activity.

Vital staining experiments with Alcian Blue conducted on nematodes within the siliceous agglutinations revealed the very sticky, elastic and contractile mucus threads emanating from the caudal gland pores in both species. The thread thickness is only about $1 \mu \mathrm{m}$. In Adoncholaimus a blue stained plug-like infilling in the barrel-shaped mouth region was often observed (in 6 of 10 individuals in one series). This substance, presumably saliva, protruded sometimes to the exterior in front of the lips. In Anoplostoma such a plug of stainable substance in the mouth was small and located close to the lips.

During staining we observed the extrusion of a mucus thread from the ventral gland pore in three individuals of Adoncholaimus. These threads were as sticky and elastic as those produced by the caudal glands, and the thickness of an extended thread fixed to particles was about $1 \mu \mathrm{m}$.

\section{Evidence for $\beta$-glucosidase activity}

In agar preparations containing the fluorogenic methylumbelliferyl- $\beta$-glucoside (MUF) and Adoncholaimus thalassophygas, an enhanced substrate fluorescence was visible under the epifluorescence microscope after an incubation time of about 2 hours. This fluorescence indicated $\beta$-glucosidase activity; its intensity increased during the next few hours and, after one day, was visible to the naked eye using a normal UV lamp (Hanau UV-Fluotest). Fluorescence was observed in assays processed both with and without a prior antibiotic treatment of the worms. In the latter, microbial growth was visible after $24 \mathrm{~h}$, whereas in the former no growth occurred after that period. The nematodes crawled vigorously during the first hours of the experiments, but became inactive towards the end of the observation period due to coverslip pressure and other unknown factors. Variations in the intensity of fluorescence were noted between microscopic preparations, and sometimes clouds with a stronger fluorescence were observed. An increased fluorescence was noted in one experiment around parts of Adoncholaimus individuals that were crushed with a needle. Unfortunately, because the fluorescence tended to fade in the UV light during extended periods of observation, we could not locate the precise sites where the fluorescence originated. 


\section{Discussion}

\section{Nematodes contribute to polysaccharidase enzyme systems in sediments}

The evidence for an extracorporeal $\beta$-glucosidase activity in cultures with Adoncholaimus thalassophygas, and our agar-plate observations, have provided new clues on the significance of nematodes in the detritus food chains and may explain the function of their detrital agglutinations. Extracorporeal discharge of various digestive enzymes has been previously reported for a number of plant-parasitic and animal-parasitic nematodes (see Lee \& Atkinson, 1976, for review), but the suspected occurrence of such an activity in free-living aquatic nematodes, mentioned in the 'Problem', remained hypothetical.

We observed that members of three nematode families (Oncholaimidae, Anoplostomatidae, Comesomatidae) promoted a conspicuous microbial growth on their trails in agar plates, and with some reservation we can add members of three other common marine families (Monhysteridae, Xyalidae and Enoplidae), that generate similar effects, as was displayed on the micrographs of Jensen (1996, which also showed trails of the comesomatid Sabatieria pulchra). Thus, it appears that these conditions represent a lifehabit trait of aquatic nematodes that can be generalised.

Based on Meschkat (1934), who described a continuous mucus discharge by crawling nematodes, Riemann (1986) tacitly assumed that secretions provided the nutritive substrate for microbial growth, comparable to the results found with gastropods (Peduzzi \& Herndl, 1991; for contrasting results with triclad plathelminths see Calow, 1979). Our present experiments with oncholaimids in mineral sediments (diatomaceous earth) demonstrated no substantial discharge of nutritive mucus to support the development of massive microbe aggregates as were seen in the oligotrophic agar plates. This result prompted us to consider the nematodes' capacity to discharge an enzyme that hydrolyses refractory agar components, thus liberating low molecular sugars which can be assimilated by the nematodes and by their associated microbes. The main component of agar is agarose, which contains $\beta$-glucosidic bonds (Schlegel, 1981).

$\beta$-glucosidases hydrolysing cellulose (i.e. components of the cellulase system) and other refractory carbohydrates have long been reported to be produced by plant-attacking nematodes (see review by Deubert \& Rohde, 1971), but these studies were perpetually accompanied by doubts as to the contribution of associated microbes to the relevant hydrolysing activity. Supporting evidence in the present study for an endogenous production of $\beta$-glucosidases in nematodes comes from the growth pattern of microbe aggregates in the agar plates. They are strictly confined to the nematodes' trails for long times, up to one year or more, indicating that the worms actually contribute to the enzymatic cleavage of refractory polysaccharide compounds. If the microbes themselves had agarolytic capabilities, we would expect an extended growth all over the agar layer in the petri dish.

Smant et al. (1998) characterised four endogenous cellulase ( $\beta$-1,4-endoglucanase) genes in two species of plant-parasitic tylenchid nematodes and assumed that the ability to produce cellulases endogenously might be widely distributed within the Nematoda. However, all previous indications for such activity derive from observations of the subclass Secernentea, while evidence from the subclass Adenophorea, which dominates in 
marine habitats, was lacking. Homology with bacterial cellulases raised the question (Smant et al., 1998) whether nematodes have acquired their cellulases by horizontal gene transfer from a prokaryote. There is the possibility that the acquisition of these genes is based on a comparatively recent event that is not manifest in all phylogenetic branches of the Nematoda. Therefore, a future molecular analysis of adenophoreans (e. g., oncholaimids) for the presence of the same cellulase genes is desirable not only because of its ecophysiological relevance but also for phylogenetic information.

Smant et al. (1997) demonstrated that exposure to potato root diffusate triggers the secretion of the cellulase-containing pharyngeal gland proteins in plant-parasitic tylenchids. Accordingly, environmental factors probably also induce and repress the relevant enzymatic activity in aquatic nematodes. In the agar-plate experiments the spectacular bacterial growth was restricted to few days only, and it appears that this period is limited by the termination of the nematodes' enzymatic activity.

Fluorogenic methylumbelliferyl-substrates (MUF) have been used as substrate analogs (Hoppe, 1983; methodological limitations are discussed by King, 1986) to analyse polysaccharidase enzyme activity in sediments, mainly with microbiological perspectives (Meyer-Reil, 1986; King, 1986; Boetius, 1995). Employing another technique, Faubel \& Meyer-Reil (1983) attempted to identify the proportion of degradation rates caused by meiofauna versus micro-organisms. In a sandy beach sediment, the meiofauna (dominated by Oligochaeta) contributed one third of the total $\beta$-glucosidase activity, but the authors assumed that a considerable amount of this activity could be derived from micro-organisms that they found in the digestive tracts of the oligochaetes. No attempt was made to axenise the animals in order to assess that amount.

Nematodes accelerate the decomposition processes of polysaccharide-rich plant detritus. Examples of experiments conducted with marine nematodes are presented by Findley \& Tenore (1982) and Alkemade et al. (1992). Grazing on bacteria, because of the concomitant maintenance of the microbial community in the log phase of growth, and bioturbation effects have been discussed among others (see also Lee, 1980) as causes for the higher mineralisation rates in the presence of nematodes. Based on our present results with artificial glucosides we now consider the possibility that nematodes with endogenous $\beta$-glucosidases interact in a more direct way with micro-organisms to decompose refractory polysaccharides. Cellulose and other refractory carbohydrates are degraded in soils and aquatic sediments mainly by fungi and bacteria which produce a number of synergistically operating cellulases that attack structurally different compounds of these most abundant natural polymers (Beguin \& Aubert, 1994). We suggest that aquatic nematodes may deliver enzymes supplementary to the complex microbial cellulase system.

The attraction of degrading cellulose for nematodes is relevant here. Such an attraction was reported by Franz (1942) for secernentean soil nematodes (see 'Problem'). In marine habitats, Meyers \& Hopper $(1966,1967,1973)$ observed the attraction of oncholaimid nematodes to fungus-degraded cellulose substrates in the field and reported on a numerically large and diverse nematode population in degraded cotton cellulose filters of a laboratory seawater system (1967). They concluded (1973) that the activity of nematodes may be correlated with microbial conversion of plant cellulose in the ecosystem. Other types of polysaccharides are also attractive. Heip et al. (1985, p. 461) observed the concentration of juvenile and adult Oncholaimus oxyuris around tracks made by the polychaete Nereis diversicolor. This observation concurs with our opinion 
related to the mucopolysaccharidic nature of the tracks, because oncholaimids are attracted also to the mucus tracks of tubificid oligochaetes (Riemann, unpublished). Riemann (1995) presented examples of the concentration of nematodes in freshly sedimented gelatinous aggregates of plankton organisms, also noting the preferential immigration of nematodes into agar media. In all these cases of attractive polysaccharides, the $\beta$-glucosidase potential of nematodes could have a direct nutritive significance as it may yield monomeric carbohydrates that can be consumed by the worms.

\section{The role of associated heterotrophic microbes in the nutrition of benthic nematodes: questions to a paradigm}

Nematode behaviour in the microbe-loaded trails in agar plates did not include browsing on bacteria. Studies on oncholaimids and other nematodes in degrading cellulose detritus (Meyers \& Hopper, 1967; Riemann \& Schrage, 1978; Lopez et al., 1979) likewise failed to demonstrate uptake of micro-organisms involved in the cellulose degradation process (although an unnoticed uptake of other microbiota in the community was surmised). This is an unexpected result, since abundant species of several nematode families occurring in detrital habitats have been demonstrated to feed on bacteria (Nicholas, 1984; Schiemer, 1987, for reviews; modern examples: Herman \& Vranken, 1988; Moens \& Vincx, 2000). In our opinion, however, the issue of the generally assumed high nutritive value of bacteria cell contents for benthic nematodes is still not settled despite intensive research over many years (for old literature, see Overgaard Nielsen, 1949; Hirschmann, 1952).

The failure to demonstrate bacteria-grazing, together with the evidence presented here that several nematode species may directly use components of refractory polysaccharides, suggests a shift in prevailing concepts on the relative nutritional significance of elements of the detritus complex (particulate substrate, sorbed dissolved substances, and the residing microbial community: detritus definition by Christian \& Wetzel, 1978). Remarkably, the pertaining debate on the significance of microbial versus nonliving fractions also continues in studies on macrobenthic deposit feeding. Lopez \& Levinton (1987) reviewed the validity of the paradigmatic "microbial stripping hypothesis" in the nutrition of detritus feeders and called particular attention to nonliving fractions.

Concerning nonliving nitrogenous food resources for detritus feeders, nematodes provide a special physiological argument. The intestines of benthic nematodes apparently lack an efficient endogenous proteolytic digestion system (compare Jennings \& Colam, 1970; Lee \& Atkinson, 1976; Deutsch, 1978; Nuss, 1985; Van de Velde \& Coomans, 1989). Only colloids may be processed by endocytosis in the intestine or (as was observed in Anoplostoma) in the epidermis (Nuss, 1985). Accordingly, in order to assimilate sizeable particulate food like microbe cells, the nematodes must rely on enzymes of foreign origin or on autolytic processes initiated by mechanical damage to the ingested cells. Terrestrial and freshwater plectids and rhabditids, both notorious bacteria-feeders (Nicholas, 1984), possess sclerotised elements in their pharynges which might be suitable for squeezing bacteria. Most marine nematodes from detrital habitats, however, lack bacteria-destroying mechanisms in their pharynges. If bacteria are taken 
up, they may persist for four days undigested in the intestine of the monhysterid Diplolaimella sp. (Deutsch, 1978).

Consequently, the apparent lack of efficient proteolytic capabilities in a number of marine nematodes abounding in detrital sediments (e.g., Diplolaimella spp.) suggests the existence and use of a pool of labile nitrogen compounds other than microbial protein in this habitat. These compounds, probably dissolved or adsorbed amino acids (about 5 to $10 \%$ of the total amino acids in North Sea sediments are available without application of proteolytic enzymes: Dauwe et al., 1999), may represent the nitrogenous food for nematodes in detrital aquatic habitats.

\section{Nematodes and heterotrophic microbes in detrital habitats: the 'enzyme-sharing' concept}

The lack of an efficient endogenous proteolytic digestion system in the intestines of benthic nematodes may be compensated by microbial proteolytic activity in the ambient detritus. Data on such activity in muddy sand of the Kiel Bight have been presented by Meyer-Reil (1986). Very high activity values were found by Boetius (1995) and Boetius \& Lochte (1996) in deep-sea sediments. Disturbance of sediment may boost values an order of magnitude higher compared to undisturbed sediments; this should be considered in the context of bioturbation effects on microbial populations (Meyer-Reil, 1986). The incessant movements of most benthic nematodes are relevant here.

Detrital aggregates in the water column may serve as model microhabitats comparable to detrital agglutinations produced by the nematodes. Smith et al. (1992; see also Martinez et al., 1996) noted an intense bacterial hydrolytic (mainly proteolytic) enzyme activity on water column aggregates and they implied rapid particle dissolution, during which most of the hydrolysates of particulate combined amino acids (about $97 \%$ ) diffuse away. There are indications that protein is solubilised faster than polysaccharide. The sinking aggregate was conceived as an "enzymatic reactor", fuelled not only by the particulate organic material of the aggregate itself, but also by the suspended particles and colloids it accretes. In marine-snow studies nematodes have been found occasionally in water column aggregates, and an anecdotal report by Shanks \& Walters (1997) precisely described what we expect many aquatic nematodes from benthic detrital habitats will do: "Nematodes were observed to remain in aggregates throughout the observation period adding material from the surrounding water to the home aggregate". This sentence repeats the essence of what Meschkat (1934) had written. Accordingly, the perpetual accretion of detrital organic particles could be an adaptation of nematodes to run the machinery of an "enzymatic reactor".

Finally, we recognise a relationship of mutual commensalism of nematodes and heterotrophic microbes in detrital habitats. We propose the term 'enzyme sharing' to describe this relationship. Both parties invest in a common enzyme pool that decomposes organic detritus for their nutrition. Our experiments provide evidence that nematodes contribute $\beta$-glucosidase involved in the cellulase system. The literature data suggest that microbial enzymatic processing of detrital proteins yields amino acids available as food for nematodes, whose intestines apparently lack an efficient proteolytic enzyme system. 


\section{Conclusions}

In conclusion, we agree with the statement of Pomeroy (1979) concerning trophic level concepts applied to detrital systems: "While it is relatively straightforward to organise the classical plant-grazer-carnivore structure into trophic levels, the microbial community, living at the expense of a variety of particulate and dissolved substrates, does not fit that scheme. Although there are several energy transfer steps between substrate, bacteria and grazers, both protozoan and metazoan, they cannot be separated into neat, distinct, trophic levels. This would be a trivial problem had not ecologists given the trophic level concept such a strong sense of reality."

Most arguments in our enzyme-sharing concept derive from observations made on nematodes belonging to the family Oncholaimidae (Subclass Adenophorea). Oncholaimids are abundant in coastal waters, are easily kept in the laboratory (though a continuous reproduction has not yet been achieved, see Moens \& Vincx, 1998), and have often been used for experimental studies. The conclusions on the role of nematodes in detrital habitats depend, of course, on the extent to which these studies can be generalised. "The success of nematodes in inhabiting such a wide range of environments rests on their physiological, behavioural and biochemical adaptations, not on their structural diversity" (Nicholas, 1984). It is this functional diversity of the class that makes the designation of a 'model nematode', applicable for the elucidation of ecosystem processes, a difficult task; it can only be solved by the joint efforts of ecologists and taxonomists.

\section{Acknowledgements}

We thank R. Amann and Heike Eilers (Max-Planck Institute for Marine Microbiology, Bremen) and H.-J. Rüger (AWI Bremerhaven) for their generous help and advice in bacteriological questions. The senior author is grateful to Gertrud Köhler for her technical assistance during many years and to B. Biddanda and G. Lopez for the hours filled with informative talks on detrital biota during our former collaborations in Bremerhaven, and to A. L. Rice (Farnham, UK) for special 'Freundschaftsdienste'. Critical and helpful comments to the manuscript by Jörg Ott and his reviewing staff are gratefully appreciated.

\section{References}

Alkemade, R., A. Wielemaker, S. A. de Jong \& A. J. J. Sandee, 1992: Experimental evidence for the role of bioturbation by the marine nematode Diplolaimella dievengatensis in stimulating the mineralization of Spartina anglica detritus. Mar. Ecol. Prog. Ser., 90: 149-155.

Beguin, P. \& J.-P. Aubert, 1994: The biological degradation of cellulose. FEMS Microbiol. Rev., 13: $25-58$.

Boetius, A., 1995: Microbial hydrolytic enzyme activities in deep-sea sediments. Helgol. Meeresunters., 49: 177-187.

Boetius, A. \& K. Lochte, 1996: Effect of organic enrichments on hydrolytic potentials and growth of bacteria in deep-sea sediments. Mar. Ecol. Prog. Ser., 140: 239-250.

Bongers, T., 1983: Bionomics and reproductive cycle of the nematode Leptosomatum bacillatum living in the sponge Halichondria panicea. Neth. J. Sea Res., 17: 39-46.

Calow, P., 1979: Why some metazoan mucus secretions are more susceptible to microbial attack than others. Am. Nat., 114: 149-152.

Cayrol, J. C. \& M. M. B'chir, 1973: Rôle de divers nématodes saprophages sur la multiplication de bactéries associées a quelque dépérissement du champignon de couche. Ann. Phytophathol., 4: 409.

Cayrol, J.C. \& B. Dreyfus, 1975: Etudes préliminaires sur les relations entre nématodes libres et bactéries dans le sol. C. R. Séances Soc. Biol. Fil., 169: 166-172.

Chia, F.-S. \& R. M. Warwick, 1969: Assimilation of labelled glucose from seawater by marine nematodes. Nature, 224: 720-721. 
Christian, R. R. \& R. L. Wetzel, 1978: Interaction between substrate, microbes, and consumers of Spartina detritus in estuaries. In: M. L. Wiley (Ed.), Estuarine interactions. Academic Press, New York: 93-113.

Coomans, A. \& D. De Waele, 1979: Species of Aphanolaimus (Nematoda, Araeolaimida) from Africa. Zool. Scr., 8: $171-180$.

Dauwe, B., J. J. Middelburg, P. Van Rijswijk, J. Sinke, P. M. J. Herman \& C. H. R. Heip, 1999: Enzymatically hydrolyzable amino acids in North Sea sediments and their possible implication for sediment nutritional values. J. Mar. Res., 57: 109-134.

Deubert, K. H. \& R. A. Rohde, 1971: Nematode enzymes. In: B. M. Zuckerman, W. F. Mai \& R. A. Rohde (Eds.), Plant parasitic nematodes. Vol. 2. Academic Press, New York: 73-90.

Deutsch, A., 1978: Gut ultrastructure and digestive physiology of two marine nematodes, Chromadorina germanica (Bütschli, 1874) and Diplolaimella sp. Biol. Bull., 155: 317-335.

Faubel, A. \& L.-A. Meyer-Reil, 1983: Measurement of enzymatic activity of meiobenthic organisms: methodology and ecological application (1). Cah. Biol. Mar., 24: 35-49.

Findlay, S. \& K. R. Tenore, 1982: Effect of a free-living marine nematode (Diplolaimella chitwoodi) on detrital carbon mineralization. Mar. Ecol. Prog. Ser., 8: 161-166.

Franz, H., 1942: Untersuchungen über die Kleintierwelt alpiner Böden. I. Die freilebenden Erdnematoden. Zool. Jahrb. (Syst.), 75: 365-546.

Gerlach, S. A., 1978: Food-chain relationships in subtidal silty sand marine sediments and the role of meiofauna in stimulating bacterial productivity. Oecologia, 33: 55-69.

Heip, C., M. Vincx \& G. Vranken, 1985: The ecology of marine nematodes. Oceanogr. Mar. Biol. Annu. Rev., 23: 399-489.

Herman, P. M. J. \& G. Vranken, 1988: Studies of the life-history and energetics of marine and brackish-water nematodes. II. Production, respiration and food uptake by Monhystera disjuncta. Oecologia, 77: 457-463.

Hirschmann, H., 1952: Die Nematoden der Wassergrenze mittelfränkischer Gewässer. Zool. Jahrb. (Syst.), 81: $313-436$.

Hoppe, H.-G., 1983: Significance of exoenzymatic activities in the ecology of brackish water: measurements by means of methylumbelliferyl-substrates. Mar. Ecol. Prog. Ser., 11: 299-308.

Jennings, J. B. \& J. B. Colam, 1970: Gut structure, digestive physiology and food storage in Pontonema vulgaris (Nematoda: Enoplida). J. Zool., London, 161: 211-221.

Jensen, P., 1996: Burrows of marine nematodes as centres for microbial growth. Nematologica, 42: 320-329.

King, G. M., 1986: Characterization of $\beta$-glucosidase activity in intertidal marine sediments. Appl. Environ. Microbiol., 51: 373-380.

Lee, D. L. \& H. J. Atkinson, 1976: Physiology of nematodes. $2^{\text {nd }}$ edition. Macmillan Press, London; 215 pp.

Lee, J. J., 1980: A conceptual model of marine detrital decomposition and the organisms associated with the process. In: R. M. Droop \& H. W. Jannasch (Eds.), Advances in aquatic microbiology. Vol. 2. Academic Press, London: 257-291.

Lopez, G., F. Riemann \& M. Schrage, 1979: Feeding biology of the brackish-water oncholaimid nematode Adoncholaimus thalassophygas. Mar. Biol., 54: 311-318.

Lopez, G. R. \& J. S. Levinton, 1987: Ecology of deposit-feeding animals in marine sediments. Q. Rev. Biol., 62: $235-260$

Lorenzen, S., 1979: Marine Monhysteridae (sensu stricto, Nematodes) von der südchilenischen Küste und aus dem küstenfernen Sublitoral der Nordsee. Stud. Neotrop. Fauna Environ., 14: 203-214.

Martinez, J., D. C. Smith, G. F. Steward \& F. Azaam, 1996: Variability in ectohydrolytic enzyme activities of pelagic marine bacteria and its significance for substrate processing in the sea. Aquat. Microb. Ecol., 10: 223-230.

Meschkat, A., 1934: Der Bewuchs in den Röhrichten des Plattensees. Arch. Hydrobiol., 27: 436-517.

Meyer-Reil, L.-A., 1986: Measurement of hydrolytic activity and incorporation of dissolved organic substrates by microorganisms in marine sediments. Mar. Ecol. Prog. Ser., 31: 143-149.

Meyers, S. P. \& B. E. Hopper, 1966: Attraction of the marine nematode, Metoncholaimus sp., to fungal substrates. Bull. Mar. Sci., 16: 142-150.

Meyers, S. P. \& B. E. Hopper, 1967: Studies on marine fungal-nematode associations and plant degradation. Helgol. wiss. Meeresunters., 15: 270-281.

Meyers, S. P. \& B. E. Hopper, 1973: Nematological-microbial interrelationships and estuarine biodegradative processes. In: L. H. Stevenson \& R. R. Colwell (Eds.), Estuarine microbial ecology. Univ. South Carolina Press, Columbia: 483-489.

Moens, T., L. Verbeeck \& M. Vincx, 1999: Feeding biology of a predatory and a facultatively predatory nematode (Enoploides longispiculosus and Adoncholaimus fuscus). Mar. Biol., 134: 585-593.

Moens, T. \& M. Vincx, 1998: On the cultivation of free-living marine and estuarine nematodes. Helgol. Meeresunters., 52: 115-139.

Moens, T. \& M. Vincx, 2000: Temperature, salinity and food thresholds in two brackish-water bacterivorous nematode species: assessing niches from food absorption and respiration experiments. J. Exp. Mar. Biol. Ecol., 243: 137-154. 
Mountain, W. B. \& Z. A. Patrick, 1959: The peach replant problem in Ontario. VII. The pathogenity of Pratylenchus penetrans (Cobb, 1917) Filip. \& Stek. 1941. Can. J. Bot., 37: 459-470.

Nehring, S., P. Jensen \& S. Lorenzen, 1990: Tube-dwelling nematodes: tube construction and possible effects on sediment-water interfaces. Mar. Ecol. Prog Ser., 64: 123-128.

Nicholas, W. L., 1984: The biology of free-living nematodes. $2^{\text {nd }}$ edition. Clarendon Press, Oxford; $251 \mathrm{pp}$.

Nuss, B., 1985: Ultrastrukturuntersuchungen zur Nahrungsabsorption von aquatischen Nematoden. Veröff. Inst. Meeresforsch. Bremerhaven, 21: 1-69.

Overgaard Nielsen, C., 1949: Studies on the soil microfauna. II. The soil inhabiting nematodes. Natura Jutl., 2: $1-131$.

Peduzzi, P. \& G. J. Herndl, 1991: Mucus trails in the rocky intertidal: a highly active microenvironment. Mar. Ecol. Prog Ser., 75: 267-274.

Platt, H. M. \& R. M. Warwick, 1980: The significance of free-living nematodes to the littoral ecosystem. In: J. H. Price, D. E. G. Irvine \& W. F. Farnham (Eds.), The shore environment. Vol. 2. Academic Press, London and New York: 729-759.

Pomeroy, L. R., 1979: Microbial roles in aquatic food webs. In: R. R. Colwell \& J. Foster (Eds.), Aquatic microbial ecology. Maryland Sea Grant Publication, University of Maryland: 85-109.

Riemann, F., 1986: Berichte der Abteilungen. Nematodenkunde. Veröff. Inst. Meeresforsch. Bremerhaven, 21: $195-201$.

Riemann, F., 1995: The deep-sea nematode Thalassomonhystera bathislandica sp. nov. and microhabitats of nematodes in flocculent surface sediments. J. Mar. Biol. Assoc. UK, 75: 715-724.

Riemann, F., W. Ernst \& R. Ernst, 1990: Acetate uptake from ambient water by the free-living marine nematode Adoncholaimus thalassophygas. Mar. Biol., 104: 453-457.

Riemann, F. \& M. Schrage, 1978: The mucus-trap hypothesis on feeding of aquatic nematodes and implications for biodegradation and sediment texture. Oecologia (Berlin), 34: 75-88.

Riemann, F. \& M. Schrage, 1988: Carbon dioxide as an attractant for the free-living marine nematode Adoncholaimus thalassophygas. Mar. Biol., 98: 81-85.

Schiemer, F., 1987: Nematoda. In: T. J. Pandian \& F. J. Vernberg (Eds.), Animal energetics. Vol. 1. Academic Press, New York: 185-211.

Schlegel, H. G., 1981: Allgemeine Mikrobiologie. 5. Aufl. Georg Thieme, Stuttgart; 559 pp.

Shanks, A. L. \& K. Walters, 1997: Holoplankton, meroplankton, and meiofauna associated with marine snow. Mar. Ecol. Prog. Ser., 156: 75-86.

Smant, G., A. Goverse, J. P. W. G. Stokkermans, J. M. De Boer, H. (R.) Pomp, J. F. Zilverentant, H. A. Overmars, J. Helder, A. Schots \& J. Bakker, 1997: Potato root diffusate-induced secretion of soluble, basic proteins originating from the subventral esophageal glands of potato cyst nematodes. Phytopathology, 87: 839-845.

Smant, G., J. P. W. G. Stokkermans, Y. Yan, J. M. De Boer, T. J. Baum, X. Wang, R. S. Hussey, F. J. Gommers, B. Henrissat, E. L. Davis, J. Helder, A. Schots \& J. Bakker, 1998: Endogenous cellulases in animals: Isolation of $\beta$-1,4-endoglucanase genes from two species of plant-parasitic cyst nematodes. Proc. Natl Acad. Sci. USA, 95: 4906-4911.

Smith, D. C., M. Simon, A. L. Alldredge \& F. Azam, 1992: Intense hydrolytic enzyme activity on marine aggregates and implications for rapid particle dissolution. Nature, 359: 139-142.

Tracey, M. V., 1958: Cellulase and chitinase in plant nematodes. Nematologica, 3: 179-183.

Turpeenniemi, T. A. \& H. Hyvärinen, 1996: Structure and role of the renette cell and caudal glands in the nematode Sphaerolaimus gracilis (Monhysterida). J. Nematol., 28: 318-327.

Van de Velde, M.C. \& A. Coomans, 1987: Ultrastructure of the excretory system of the marine nematode Monhystera disjuncta. Tissue \& Cell, 19: 713-725.

Van de Velde, M. C. \& A. Coomans, 1989: Ultrastructure of the anterior intestine in monhysterids (Nematoda). Ann. Soc. R. Zool. Belg., 119: 109-119.

Warwick, R. M., 1981: Survival strategies of meiofauna. In: N. V. Jones \& W. J. Wolff (Eds.), Feeding and survival strategies of estuarine organisms. Plenum Press, New York: 39-52.

Wesenberg-Lund, C., 1939: Biologie der Süsswassertiere. Wirbellose Tiere. Julius Springer, Wien; 817 pp. 